Open Access

\title{
Investigating the possibility of producing animal feed from sugarcane bagasse using oyster mushrooms: a case in rural entrepreneurship
}

\author{
Mojtaba Mahmood Molaei Kermani, Samaneh Bahrololoum ${ }^{*}$ and Farzaneh Koohzadi
}

\author{
* Correspondence: \\ samanehbahrololoum@gmail.com \\ Department of Biotechnology and \\ Plant Breeding, Ferdowsi University \\ of Mashhad, Mashhad, Iran
}

\begin{abstract}
Pleurotus florida is an edible mushroom that has commercial potential in the food industry. The objective of this study was to investigate the possibility of producing animal feed from sugarcane bagasse using $P$. florida. To this aim, sugarcane bagasse was processed with $P$. florida. The experiment was designed in a completely randomized design with four treatments: processed sugarcane bagasse, raw sugarcane bagasse, wheat straw, and barley straw. This research was carried out under two in vitro and in vivo conditions. In case of in vitro condition, it can be concluded that the amount of dry matter, neutral detergent fiber $(P<0.01)$, and acidic detergent fiber $(P<0.05)$ significantly decreased in processed sugarcane bagasse, and the amount of crude protein $(P<0.05)$, organic matter, and crude ash $(P<0.01)$ significantly increased. The result of in vivo condition showed that as a result of biological processing of sugarcane bagasse with $P$. florida, the indices such as digestibility, voluntary feed intake, and relative palatability index increased. The results of this study suggests that treated bagasse could be used as an alternative roughage source for ruminant feeding.
\end{abstract}

Keywords: Animal feed, Sugarcane bagasse, Oyster mushrooms, Agricultural waste

\section{Introduction}

Currently there has been an increasing tendency towards more efficient utilization of agro-industrial residues such as sugar cane bagasse, cassava bagasse sugar beet pulp, apple pomace, etc. So far, various mechanical, physical, chemical, and biological methods have been developed to utilize these residues as raw materials for the production of chemicals, ethanol, single-cell protein, enzymes, amino acids, biologically active secondary metabolites, etc. (Pandey, Soccol, Nigam, \& Soccol, 2000; Pandey et al., 1988). Agro-industrial residues, which are semiarid and actually contain lignocellulosic material, are unsuitable for direct consumption by animals, and so they must be treated both mechanically and chemically to become edible. Also, fiber residue is low in nutritional value and need supplements to improve their nutritional value (Chaudhry, 1998; Chaudhry \& Miller, 1996). Cellulose and hemicellulose have a high digestibility, but lignin gives them hard physical structure and resistance to digestive enzymes. So far, a lot of research has been conducted to isolate lignocellulosic bonds.

(c) The Author(s). 2019 Open Access This article is distributed under the terms of the Creative Commons Attribution 4.0 International License (http://creativecommons.org/licenses/by/4.0/), which permits unrestricted use, distribution, and reproduction in any medium, provided you give appropriate credit to the original author(s) and the source, provide a link to the Creative Commons license, and indicate if changes were made. 
Common methods are breaking down lignin components through chemical and biological methods (Moyson, 1991). However, there are many reports that show feeding alkali-treated sugarcane bagasse (SB) increased feed intake and body weight of ruminant (Carvalho et al., 2013). In recent decades, more attention has been given to enrichment of lignocellulose materials as a means of biological method for enrichment. Reports indicate that wheat straw processing using ligninolytic fungus, Pleurotus ostreatus, can reduce lignin, increase crude protein, and improve its digestibility. Oyster mushrooms are primary saprophytes, and it can decompose dead plant and animal tissue by releasing enzymes (Ardon, Kerem, \& Hadar, 1996). SB is one of many fibrous residues remaining after the extraction of juice from cane stem and could be used as feed for animals ( $\mathrm{Yu}$ et al., 2013). It has been reported that SB contain low protein $(<3 \% \mathrm{DM})$, high cellulose (>40\% DM), hemicellulose (>35\% DM), and lignin (>15\% DM), and low digestibility (20-30 \% DM) (da Costa, de Souza, Saliba, \& Carneiro, 2015; Gunun et al., 2016). These attributes result poor animal performances, but through the development of physical, chemical, and biological treatments to disrupt the lingo-cellulose complex, potential use of SB as a feed may be realized (Okano et al., 2006; Balgees et al., 2007). Over the years, a large number of microorganisms such as yeasts, bacteria, and fungi have been used to improve its performances. Among these, filamentous fungi, especially basidiomycetes, are the preferred choice for enzyme production and protein enrichment and have been widely employed (Pandey et al., 2000). Abdollah et al. (2001) developed a system whereby lignin biodegradation in lignocellulosic units are optimized with the minimum loss of cellulose and the maximum loss of lignin, during a 21-day solid-state fermentation of SB with Termitomyces sp., fortified with different concentrations of sucrose and glucose. The maximum lignin loss of $27.0 \%$ and the minimum cellulose loss of $8.5 \%$ occurred when the substrate was fortified with $5 \%$ glucose. Also, the highest cow reticulorumen digestibility of $24.4 \%$, compared with $11.5 \%$ of the raw SB, was observed in this study. According to Zhang, Gong, and Li (1995), under solid-state fermentation, the crude protein contents were increased from 24.1 to $32.3 \%$ and from 28.4 to $36.7 \%$ for Pleurotus ostreatus and Lentinus edodes spent compost media, respectively. The crude fiber contents of the composts were significantly decreased, and the in vitro digestibility of the crude protein was as high as $70 \%$; the total and essential amino acid contents made up 73.3 and $37.1 \%$ of the crude protein, respectively. Therefore, mushroom substrate is a potential source of nitrogen for poultry and animals.

\section{Materials and methods}

Producing processed bagasse

Processed SB was prepared by adding lime and oyster mushroom (Pleurotus florida) spawn seed to raw SB. Raw SB is slightly acidic, so lime was added to adjust the $\mathrm{pH}$, then the SB was pasteurized for $12 \mathrm{~h}$ at $60^{\circ} \mathrm{C}$ under water vapor. After $12 \mathrm{~h}$ of pasteurization, for pre-fermentate, the SB was kept in the pasteurization room for $48 \mathrm{~h}$ at $48{ }^{\circ} \mathrm{C}$. Pasteurized compost was inoculated with $5 \%$ spawn at $30^{\circ} \mathrm{C}$, then transferred to nylon bags in dimensions of $65 \times 40 \mathrm{~cm}$. After 30 days of inoculation, the bags containing mycelium were transferred to the drying room. Over the bagasse processing, dried layers were collected and stored (Wanapat and Pimpa 1999; Wanapat et al., 2009). 


\section{Chemical composition and in vitro digestibility}

In order to evaluate the digestibility of processed SB with P. florida and compare it with other available forage, raw SB, wheat straw, and barley straw, gas production experiments were carried out using the Menke and Steingass (1988) method. In order to determine the digestibility, in vitro gas production (IVGP), crude protein (CP), and animal waste ashes (AWA) were measured in the following ways: the crude protein was determined by the Kjeldahl method described by the AOAC (1998). Animal waste ashes were determined by the protocol described by the AOAC (1998). Then, incubations were completed using $40 \mathrm{ml}$ of buffered rumen fluid. Approximately $200 \mathrm{mg}$ of feed was weighed and placed into a 120-ml graduated glass syringe according to Menke and Steingass (1988). Buffer and mineral solution was prepared and placed in a water bath at $39^{\circ} \mathrm{C}$ under continuous flushing with $\mathrm{CO}_{2}$. Rumen fluid was collected from animals into a pre-warmed thermos flask, and then filtered and flushed with $\mathrm{CO}_{2}$. The mixed and $\mathrm{CO}_{2}$-flushed rumen fluid was added to the buffered mineral solution $(1: 2(v / v))$. Buffered rumen fluid $(40 \mathrm{ml})$ was pipetted into each syringe containing feed samples, and the syringes were immediately placed into an incubator with a rotating disc, as described in Menke and Steingass (1988). Then, gas production was recorded at 2, $4,8,12,16$, and $24 \mathrm{~h}$ of incubation. The volume of producing gas at any time was calculated according to Theodorou, Williams, Dhanoa, McAllan, and France (1994). Finally, in vitro organic matter digestibility (IVOMD) was calculated as described by Menke and Steingass (1988):

$$
\operatorname{IVOMD}(g / 100 g \text { DM })=14.88+(0.889 \times \operatorname{IVGP})+(0.448 \times \mathrm{CP})+(0.651 \times \mathrm{XA})
$$

where IVGP is the total volume of produced gas from $200 \mathrm{gr}$ of feed sample after $24 \mathrm{~h}$ $(\mathrm{ml} / 200 \mathrm{gr}), \mathrm{CP}$ is the crude protein content (gr/100 gr of dry matter), and XA is the amount of ash (gr/100 gr of dry matter).

\section{Voluntary feed intake and in vivo digestibility}

In this experiment, five Baluchi male sheep with an average weight of $37 \pm \mathrm{kg}$ were used. These sheep were placed separately in five locations, each location with four mangers containing four separate forages: 300 gr of alfalfa, 200 gr straw, 200 gr raw bagasse, and $200 \mathrm{gr}$ processed bagasse per daily serving. The positions of the mangers were changed daily and randomly in order to achieve best possible randomization. The experiment was conducted in the 21-day period, and feed intake was measured daily. In the last 5 days of the period, in addition to measuring the amount of feed remaining, the stool of each livestock was collected during $24 \mathrm{~h}$; also, water intake was measured every $24 \mathrm{~h}$. The relative palatability index ( $\mathrm{Pi}$ ) was measured based on the amount of alfalfa being consumed as a standard feedstock according to Kaitho et al. (1996).

$$
\mathrm{Pi}=(\mathrm{Ti} / \mathrm{Ai}) /(\mathrm{T} 1 / \mathrm{A} 1)
$$

where $\mathrm{Pi}$ is the relative palatability index, $\mathrm{T} 1$ is the amount of eaten alfalfa, $\mathrm{A} 1$ is the amount of given alfalfa, $\mathrm{Ti}$ is the amount of consumed feed, $\mathrm{Ai}$ is the amount of given feed, and $i$ is the other feed such as raw bagasse, processed bagasse, wheat straw, and barley straw. Chemical composition and in vitro digestibility were calculated by measuring the amount of dry matter (DM) as described by the AOAC method (AOAC, 1998); organic matter (OM), crude protein (CP), crude protein digestibility, and crude 
ash (ASH) were determined by the Kjeldahl method as described by the AOAC (1998). Acid detergent fiber (ADF) and neutral detergent fiber (NDF) was calculated by the method as described by Van Soest, Robertson, and Lewis (1991). The acid-insoluble ash (AIA) of feed and the stool was calculated by the method as described by Vogtmann, Pfirter, and Prabucki (1975).

Digestibility $=100-(($ feed AIA $/$ stool AIA $) \times 100)$

where AIA is acid-insoluble ash.

\section{Statistical analyses}

The experiment was conducted in a completely randomized design (CRD) with four treatments and five replications. Differences between treatment means were determined by Duncan's new multiple range tests (Steel \& Torrie, 1980), and significant effects were identified at $P<0.01$ and $P<0.05$ levels.

\section{Results and discussions}

\section{Chemical composition and in vitro digestibility}

Table 1 shows that there was a significant difference between the four fibrous materials, processed bagasse, raw bagasse, wheat straw, and barley straw, in the case of the content of crude protein $(\mathrm{CP})$, neutral detergent fiber (NDF), acidic detergent fiber (ADF), crude ash (ASH), dry matter (DM), and in vitro organic matter digestibility (IVOMD). In this experiment, the amount of $\mathrm{CP}$ content of treated $\mathrm{SB}$ was significantly increased $(P<0.01)$; these results were in agreement with Ardon et al. (1996). Since fungus has a fairly high protein content, typically $20-30 \%$ of crude protein as a percentage of dry matter, the observed increase in CP content could be attributed to the addition of mycelial protein to the SB and the secretion of protease enzymes by the fungus (Ardon et al., 1996; Chahal \& Khan, 1991).

The in vitro organic matter digestibility (IVOMD) was significantly $(P<0.01)$ increased by processing with fungi, a large part of the raw fiber, and insoluble compounds were degraded by the fungus enzymatic process and converted into soluble materials. According to result, due to the reduction in the dry weight, neutral detergent fiber (NDF), and acidic detergent fiber (ADF), the degradable and water-soluble portion increased (Table 1), which is in agreement with the results of Fazaeli et al. (2004), who reported that IVOMD increased in the wheat straw that was treated with the $P$. florida mushroom. Also, the results showed that there is a significant difference $(P<0.01)$ between various fibrous materials and the amount of in vitro gas production (IVGP). In this experiment, the least amount of IVGP was observed in raw bagasse and the highest was observed in processed bagasse. Menke and Steingass (1988) and Liu, Orskov, and

Table 1 The effect of four fibrous materials in CP, NDF, ADF, ASH, DM, and IVOMD content

\begin{tabular}{llllllll}
\hline Source of variance & $\mathrm{df}$ & $\mathrm{CP}$ & $\mathrm{NDF}$ & $\mathrm{ADF}$ & $\mathrm{ASH}$ & $\mathrm{DM}$ & IVOMD \\
\hline Fibrous materials & 3 & $4.07^{*}$ & $0.06^{* *}$ & $0.004^{*}$ & $64.43^{* *}$ & $0.006^{*}$ & $273.6^{* *}$ \\
Standard error & 12 & 0.016 & 0.021 & 0.0002 & 0.03 & 0.004 & 1.80 \\
\hline
\end{tabular}

ns not significant

${ }^{*} P<0.05$

${ }^{* *} P<0.01$ 
Table 2 The result of dietary treatments on voluntary feed intake

\begin{tabular}{|c|c|c|c|c|c|c|c|}
\hline \multirow[t]{2}{*}{ Diets, no. } & \multirow[t]{2}{*}{ Alfalfa (\%) } & \multirow[t]{2}{*}{ Straw (\%) } & \multirow{2}{*}{$\begin{array}{l}\text { Row } \\
\text { bagasse (\%) }\end{array}$} & \multirow{2}{*}{$\begin{array}{l}\text { Processed } \\
\text { bagasse (\%) }\end{array}$} & \multicolumn{3}{|c|}{ Relative palatability index (pi) } \\
\hline & & & & & $\begin{array}{l}\text { Alfalfa and } \\
\text { straw }\end{array}$ & $\begin{array}{l}\text { Row } \\
\text { bagasse }\end{array}$ & $\begin{array}{l}\text { Processed } \\
\text { bagasse }\end{array}$ \\
\hline 1 & 45.317 & 30.211 & 1.510 & 22.960 & 1 & 0.05 & 0.76 \\
\hline 2 & 41.436 & 27.624 & 6.629 & 24.309 & 1 & 0.24 & 0.88 \\
\hline 3 & 46.583 & 31.055 & 2.795 & 29.565 & 1 & 0.09 & 0.63 \\
\hline 4 & 41.782 & 28.855 & 4 & 21.169 & 1 & 0.33 & 0.76 \\
\hline 5 & 43.731 & 29.154 & 1.749 & 25.364 & 1 & 0.06 & 0.87 \\
\hline
\end{tabular}

Chen (1999) have shown that there is a relationship between gas production and soluble carbohydrates.

\section{Voluntary feed intake and relative palatability}

Inoculation sugarcane bagasse with $P$. florida caused a significant increase in the voluntary feed intake compared with raw bagasse. This result can be due to chemical changes such as cell wall decomposition in bagasse during the solid fermentation process and consequently increasing in bagasse palatability (Table 2). This result corroborates with Ardon et al. (1996), Dhanda, Garcha, Kakkar, and Makkar (1996), and Fazaeli (2008), who reported that the ruminant fed with fungus-infected bagasse as roughage sources had a higher voluntary intake compared to raw bagasse feeding $(P<0.01)$, and this could be due to the high fiber content in processed bagasse which affected the intake of animals. This means that treated SB could improve the nutritive value and potentially be used as a highquality roughage source for the ruminant. Due to processing bagasse with mushrooms, this effect avails the rumen microbes to attack the structural carbohydrates more easily, improve digestion in the rumen, increase feed passage through the digestive system, and increase feed intake and digestibility, as well as the palatability of treated bagasse (Bakshi, Gupta, \& Langar, 1985). The result of Table 2 indicates that the relative palatability index (pi) of processed bagasse has increased as a result of biological processing with $P$. florida compared to raw bagasse.

The results of apparent digestibility of dry matter, organic matter, and protein were calculated and the results are presented in Table 3.

The highest percentage of processed bagasse is assigned to diets no. 5 (25\%), $2(24 \%)$, 1 (23\%), 4 (21\%), and 3 (19.5\%) respectively. On the other hand, diets 4 (9\%), 2 (7\%), 3 (3\%), $5(2 \%)$, and $1(1 / 5 \%)$, respectively, have the highest relative percentages of raw bagasse in the diet. Table 3 shows that the highest percentage of apparent digestibility of dry matter, organic matter, and protein were obtained in diets no. 2 and 5 with the highest percentage of relative processed bagasse, and the least percentage was obtained in diets no. 3 with the least percentage of relative processed bagasse. The results of Table 3, as well as the correlation analysis, show that there is a positive correlation between the percentage of processed bagasse in all diets and the apparent digestibility of dry matter, organic matter, and protein, as increasing the percentage of processed bagasse in two rations of 5 and 2, the highest apparent digestibility of dry matter, organic matter, and protein was observed. On the other hand, diet no. 3 with the lowest percentage of processed bagasse in all diets, although, has the lowest apparent 


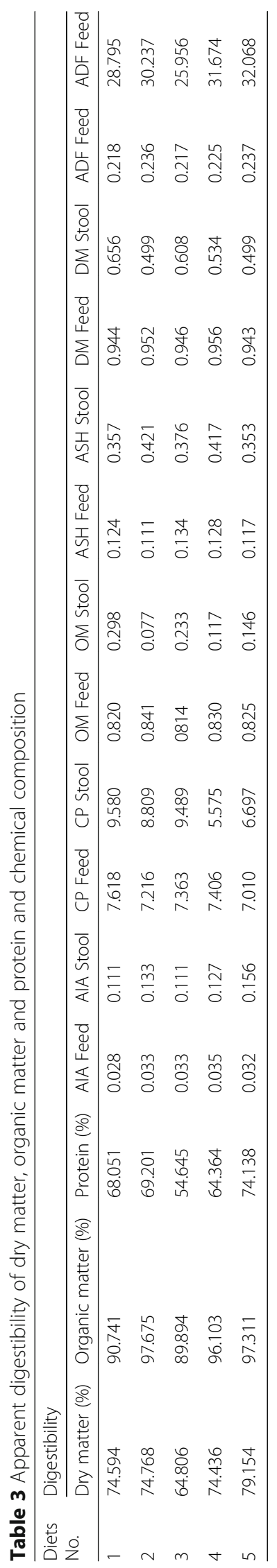


digestibility of dry matter, organic matter, and protein, despite having the highest percentage of alfalfa.

\title{
Conclusions
}

In conclusion, inoculation of sugarcane bagasse with $P$. florida could improve the nutritive value and increase digestibility, voluntary feed intake, and relative palatability index (pi). This study suggests that processed bagasse could be used as an alternative roughage source for ruminant feeding. The results show that the best economical and nutritional value was obtained with processed bagasse compared with wheat straw and barley straw. Considering the current prices, as the grain costs twice as much as the processed bagasse, so using the processed bagasse with $P$. florida is economically viable.

\begin{abstract}
Abbreviations
ADF: Acid detergent fiber; AIA: Acid-insoluble ash; AOAC: Association of Official Analytical Chemists; ASH: Crude ash; AWA: Animal waste ashes; CP: Crude protein; DM: Dry matter; IVGP: In vitro gas production; IVOMD: In vitro organic matter digestibility; NDF: Neutral detergent fiber; OM: Organic matter; Pi: Palatability index; SB: Sugarcane bagasse
\end{abstract}

\section{Acknowledgements}

Thanks to everyone who have contributed to the collection and analysis of the data as experts.

\section{Authors' contributions}

MMMK is the lead author of the study and performed the analysis of the data. SB contributed to the analysis of the data and discussion. FK contributed to the analysis and interpretation and drafted the manuscript. All authors read and approved the final manuscript.

\section{Funding}

Not applicable.

\section{Availability of data and materials}

The datasets used and analyzed during the current study are available from the corresponding author upon request.

\section{Competing interests}

The authors declare that they have no competing interests.

Received: 28 June 2019 Accepted: 16 July 2019

Published online: 26 August 2019

\section{References}

Abdullah, N., Ejaz, N., Abdullah, M., Nisa, A. U., \& Firdous, S. (2006). Lignocellulosic degradation in solid-state fermentation of sugar cane bagasse by Termitomyces sp. Micología Aplicada International, 18(2), 15-19.

AOAC (Association of Official Analytical Chemists). (1998). Official methods of analysis of theAOAC International (16th ed.). Gaithersburg: AOAC International.

Ardon, O., Kerem, Z., \& Hadar, Y. (1996). Enhancement of laccase activity in liquid cultures of the ligninolytic fungus Pleurotus ostreatus by cotton stalk extract. Journal of Biotechnology, 51(3), 201-207.

Bakshi, M. P. S., Gupta, V. K., \& Langar, P. N. (1985). Acceptability and nutritive evaluation of Pleurotus harvested spent wheat straw in buffaloes. Agricultural Wastes, 13(1), 51-57.

Balgees, A., Elmnan, A., Fadel Elseed, A. M. A., \& Salih, A. M. (2007). Effect of ammonia and urea treatments on the chemical composition and rumen degradability of bagasse. J. Appl. Sci. Res, 3(11), 1359-1362.

Carvalho, M. L., Sousa Jr, R., Rodriguez-Zuniga, U. F., Suarez, C. A. G., Rodrigues, D. S., Giordano, R. C., \& Giordano, R. L. C. (2013). Kinetic study of the enzymatic hydrolysis of sugarcane bagasse. Brazilian Journal of Chemical Engineering, 30(3), 437-447.

Chahal, D. S., \& Khan, S. M. (1991). Production of mycelial biomass of oyster mushrooms on rice straw. In Mushroom Science XIII. Volume 2. Proceedings of the 13th international congress on the science and cultivation of edible fungi (pp. 709-716). Dublin: Irish Republic.

Chaudhry, A. S. (1998). Nutrient composition, digestion and rumen fermentation in sheep of wheat straw treated with calcium oxide, sodium hydroxide and alkaline hydrogen peroxide. Animal feed science and technology, 74(4), 315-328.

Chaudhry, A. S., \& Miller, E. L. (1996). The effect of sodium hydroxide and alkaline hydrogen peroxide on chemical composition of wheat straw and voluntary intake, growth and digesta kinetics in store lambs. Animal feed science and technology, 60(1-2), 69-86.

da Costa, D. A., de Souza, C. L., Saliba, E. D. O. S., \& Carneiro, J. D. (2015). By-products of sugar cane industry in ruminant nutrition. International Journal Advance Agriculture Research, 3, 1-9.

Dhanda, S., Garcha, H. S., Kakkar, V. K., \& Makkar, G. S. (1996). Improvement in feed value of paddy straw by Pleurotus cultivation. Mushroom Research, 5, 1. 
Fazaeli, H. (2008). Digestibility and voluntary intake of fungal-treated wheat straw in sheep and cow. JWSS-Isfahan University of Technology, 12(43), 523-531.

Fazaeli, H., Mahmodzadeh, H., Azizi, A., Jelan, Z. A., Liang, J. B., Rouzbehan, Y., \& Osman, A. (2004). Nutritive value of wheat straw treated with Pleurotus fungi. Asian-australasian journal of animal sciences, 17(12), 1681-1688.

Gunun, N., Wanapat, M., Gunun, P., Cherdthong, A., Khejornsart, P., \& Kang, S. (2016). Effect of treating sugarcane bagasse with urea and calcium hydroxide on feed intake, digestibility, and rumen fermentation in beef cattle. Tropical animal health and production, 48(6), 1123-1128.

Kaitho, R. J., Umunna, N. N., Nsahlai, I. V., Tamminga, S., Van Bruchem, J., Hanson, J., \& Van De Wouw, M. (1996). Palatability of multipurpose tree species: effect of species and length of study on intake and relative palatability by sheep. Agroforestry systems, 33(3), 249-261.

Liu, J. X., Orskov, E. R., \& Chen, X. B. (1999). Optimization of steam treatment as a method for upgrading rice straw as feeds. Animal feed science and technology, 76(3-4), 345-357.

Menke, K., \& Steingass, H. (1988). Estimation of the energetic feed value from chemical composition and in vitro gas production using rumen fluid. Animal Research and Development, 28, 7-55.

Moyson, E., \& Verachtert, H. (1991). Growth of higher fungi on wheat straw and their impact on the digestibility of the substrate. Applied Microbiology and Biotechnology, 36(3), 421-424.

Okano, K., lida, Y., Samsuri, M., Prasetya, B., Usagawa, T., \& Watanabe, T. (2006). Comparison of in vitro digestibility and chemical composition among sugarcane bagasses treated by four white-rot fungi. Animal Science Journal, 77(3), 308-313.

Pandey, A., \& Soccol, C. R. (1998). Bioconversion of biomass: a case study of ligno-cellulosics bioconversions in solid state fermentation. Brazilian Archives of Biology and Technology, 41(4), 379-390.

Pandey, A., Soccol, C. R., Nigam, P., \& Soccol, V. T. (2000). Biotechnological potential of agro-industrial residues. I: sugarcane bagasse. Bioresource Technology, 74(1), 69-80.

Steel, R. G. D., \& Torrie, J. H. (1980). Duncan's new multiple range test. Principles and procedures of statistics, 187-188.

Theodorou, M. K., Williams, B. A., Dhanoa, M. S., McAllan, A. B., \& France, J. (1994). A simple gas production method using a pressure transducer to determine the fermentation kinetics of ruminant feeds. Animal feed science and technology, 48(3-4), 185-197.

Van Soest, P. V., Robertson, J. B., \& Lewis, B. A. (1991). Methods for dietary fiber, neutral detergent fiber, and nonstarch polysaccharides in relation to animal nutrition. Journal of dairy science, 74(10), 3583-3597.

Vogtmann, H., Pfirter, H. P., \& Prabucki, A. L. (1975). A new method of determining metabolisability of energy and digestibility of fatty acids in broiler diets.

Wanapat, M., \& Pimpa, O. (1999). Effect of ruminal NH3-N levels on ruminal fermentation, purine derivatives, digestibility and rice straw intake in swamp buffaloes. Asian-Australasian Journal of Animal Sciences, 12(6), 904-907.

Wanapat, M., Polyorach, S., Boonnop, K., Mapato, C., \& Cherdthong, A. (2009). Effects of treating rice straw with urea or urea and calcium hydroxide upon intake, digestibility, rumen fermentation and milk yield of dairy cows. Livestock Science, 125(2-3), 238-243.

Yu, Q., Zhuang, X., Lv, S., He, M., Zhang, Y., Yuan, Z., et al. (2013). Liquid hot water pretreatment of sugarcane bagasse and its comparison with chemical pretreatment methods for the sugar recovery and structural changes. Bioresource technology, $129,592-598$.

Zhang, C. K., Gong, F., \& Li, D. S. (1995). A note on the utilisation of spent mushroom composts in animal feeds. Bioresource Technology, 52(1), 89-91.

\section{Publisher's Note}

Springer Nature remains neutral with regard to jurisdictional claims in published maps and institutional affiliations.

\section{Submit your manuscript to a SpringerOpen ${ }^{\circ}$ journal and benefit from:}

- Convenient online submission

- Rigorous peer review

- Open access: articles freely available online

- High visibility within the field

- Retaining the copyright to your article

Submit your next manuscript at $\boldsymbol{\Delta}$ springeropen.com 